Irena ICKIEWICZ ${ }^{1}$

\title{
BUILDING THERMOMODERNIZATION AND REDUCING AIR POLLUTION
}

\author{
TERMORENOWACJA BUDYNKÓW \\ A REDUKCJA ZANIECZYSZCZENIA POWIETRZA
}

\begin{abstract}
The present paper describes a technical-economic analysis of thermomodernization works in multifamily buildings and public utility facilities constructed with the use of both traditional and industrialized technologies (prefabricated large-panel concrete, Zeranska brick), built before 1990. 1441 buildings located in 7 towns were analysed. The energy consumption indicator of the buildings undergoing the analysis was the indicator of heat load demand per cubic capacity, which was established on the basis of site inspections and technical documentation. The obtained results were used in analysing the cost-effectiveness of the suggested thermomodernization works. The following were adopted as criteria of the investment effectiveness: the 'Simple Pay Back Time' (SPBT), reducing the amounts of particulate matter and sulphur dioxide polluting the air, and heat load saving (amounting to a few or even several megawatts, which, in the case of a small town, is often sufficient to cover a prospective increase in heat load demand).
\end{abstract}

Keywords: thermomodernization, reducing ordered thermal power, economic analysis, air pollution reduction

\section{Introduction}

Relatively high and constantly growing energy prices (price increases are greater than the inflation rate) have led to an interest in thermomodernization investments in residential construction which result in reducing the demand for energy and lowering energy production costs [1]. Rising thermal requirements pertaining to both new buildings and buildings after thermomodernization (the Technical Specification of 6.11.2008) as well as rising requirements considering the acceptable level of the so-called primary pollution is also significant [2]. Emissions of sulphur dioxide $\left(\mathrm{SO}_{2}\right)$, particulate matter, and carbon monoxide $(\mathrm{CO})$ are classified as primary pollution which is generated mainly during combustion of fuels in the process of energy production.

The main sources of primary pollution emission are emission sources of utility and industrial power plants (the so-called high emission), but also (in the municipal and residential sector) local boiler houses, service companies, and individual households (the so-called low emission).

\footnotetext{
${ }^{1}$ Faculty of Civil and Environmental Engineering, Bialystok University of Technology, ul. Wiejska 45 E, 15-331 Białystok, Poland, phone +48 797775 773, email: i.ickiewicz@pb.edu.pl
} 
Heat sources in the municipal and residential sector have the following three functions: meeting the current and prospective demand for energy, minimising energy prices, and the last and a very important one - reducing the negative influence on the natural environment.

Reducing the negative influence on the natural environment is one of the European Union's priorities, which is reflected in, for example, adopting by the European Parliament of the Directive 2002/91/EC which introduces the requirement of obtaining energy performance certificates for residential buildings. The purpose of the certification is to reduce energy consumption for heating purposes by limiting to the minimum heat loss through external building partitions, including glass partitions (windows), by applying optimum heating systems, and also (or perhaps above all) by 'encouraging' users to make use of renewable energy sources [2]. In order for a building under analysis to be rated high as an energy efficient one, beside having well thermally insulated partitions and an optimum heating system, heat (or at least some part of it) supplied to the building must come from renewable energy sources (through solar systems, solar cells, heat pumps, wind turbines, etc) $[3,4]$. Using renewable energy sources makes it possible to significantly reduce the design value of primary energy which indirectly characterises buildings thermally [1, 4-6].

\section{Research on energy-saving modernisation of heat management}

In the period of 1996-2010, the author of the present article participated in conducting several surveys pertaining to energy-saving modernisation of heating systems in a few middle-sized towns located in the north-eastern Poland [7, 8]. These comprehensive surveys included detailed characteristics of the elements of the existing heating systems, such as: heat sources, heat networks and heat distribution centres, buildings and their internal systems, as well as data concerning air pollution emission from the existing heat sources.

On the basis of the collected data, guidelines on investments rationalising heat consumption by recipients were developed, and economic as well as 'ecological' analyses of these investments were made. In the economic assessment of the analysed thermomodernization works, the 'Simple Pay Back Time' (SPBT) was adopted as the criterion of the investment effectiveness, whereas in the 'ecological' analysis the basic criterion was the reduction in the amounts of particulate matter and sulphur dioxide polluting the air, obtained as a consequence of lowering the heat load demand resulting from the performed comprehensive thermomodernization [9-12].

\section{Characteristics of elements of the existing heat systems in selected towns}

In the 7 towns under research (Siemiatycze, Pisz, Suwalki, Lomza, Gizycko, Hajnowka, Kolno), 1441 multi-family buildings regarded as the main recipients of heat from the heat system (apart from heat networks and heat distribution centres) were assessed thermally. The analysed buildings were made using industrialized technologies, mainly of prefabricated large-panel concrete, and Zeranska brick, as well as using traditional technologies.

The number, cubic capacity, and equipment with internal heating systems of the analysed multi-family buildings are listed in Table 1. 
Data concerning the number of buildings and their equipment with internal systems

\begin{tabular}{|c|c|c|c|c|c|c|c|c|}
\hline \multirow{4}{*}{ No. } & \multirow{4}{*}{$\begin{array}{c}\text { Town } \\
\text { number of } \\
\text { inhabitants }\end{array}$} & \multicolumn{6}{|c|}{ Number of multi-family buildings with systems } & \multirow{4}{*}{$\begin{array}{c}\text { Cubic capacity } \\
\text { of flats } \\
{\left[\mathbf{m}^{3}\right]}\end{array}$} \\
\hline & & \multicolumn{2}{|c|}{ central heating } & \multirow{2}{*}{\multicolumn{2}{|c|}{$\begin{array}{c}\text { hot water } \\
\text { from the network }\end{array}$}} & \multicolumn{2}{|c|}{ furnaces } & \\
\hline & & \multirow{2}{*}{$\begin{array}{c}\text { before } \\
2000\end{array}$} & \multirow{2}{*}{2010} & & & \multirow{2}{*}{$\begin{array}{c}\text { before } \\
2000\end{array}$} & \multirow{2}{*}{2010} & \\
\hline & & & & before 2000 & 2010 & & & \\
\hline 1. & $\begin{array}{c}\text { Siemiatycze } \\
15060\end{array}$ & 82 & 102 & 59 & 71 & 10 & 0 & 463864 \\
\hline 2. & $\begin{array}{c}\text { Pisz } \\
19700\end{array}$ & 109 & 158 & 28 & 81 & 51 & 20 & 846826 \\
\hline 3. & $\begin{array}{c}\text { Gizycko } \\
29800\end{array}$ & 286 & 312 & 167 & 193 & 21 & 5 & 1905539 \\
\hline 4. & $\begin{array}{l}\text { Lomza } \\
63820\end{array}$ & 354 & 443 & 210 & 257 & 70 & 49 & 3206512 \\
\hline 5. & $\begin{array}{l}\text { Suwalki } \\
66430\end{array}$ & 416 & 458 & 384 & 439 & \multicolumn{2}{|c|}{ no data available } & 3849400 \\
\hline 6. & $\begin{array}{c}\text { Hajnowka } \\
25000\end{array}$ & 137 & 141 & 95 & 128 & 9 & 3 & 735640 \\
\hline 7. & $\begin{array}{l}\text { Kolno } \\
11250 \\
\end{array}$ & 57 & 59 & 51 & 58 & 1 & 0 & 419229 \\
\hline & Total & 1441 & 1673 & 994 & 1227 & 162 & 77 & 11427012 \\
\hline
\end{tabular}

Indicators of heat load demand per cubic capacity in $\left[\mathrm{W} / \mathrm{m}^{3}\right]$ were adopted in assessing the energy consumption of the buildings. These indicators vary significantly for different buildings. The differences result from the ages of the particular buildings, the technologies used for constructing them, and from the fact that the buildings have various managers (owners). The values of the above indicators, irrespective of the town, range from $15 \mathrm{~W} / \mathrm{m}^{3}$ (buildings which are quite good as far as thermal insulation is concerned) to $40 \mathrm{~W} / \mathrm{m}^{3}$ (very cold buildings) [7, 8]. Buildings constructed in the 1990s (pursuant to the requirements in force at that time, described in the PN-B/91-02020 'thermal protection of buildings' standard) should have had indicators of heat load demand per cubic capacity $15-17 \mathrm{~W} / \mathrm{m}^{3}$ (the $U$ coefficient of heat transmission of a wall $\leq 0.45 \mathrm{~W} /\left(\mathrm{m}^{2} \cdot \mathrm{K}\right)$ ) [9].

Table 2

Mean indicators of heat load demand per cubic capacity, and percentages of multi-family buildings classified as cold buildings

\begin{tabular}{|c|c|c|c|c|c|c|c|}
\hline \multirow{4}{*}{ No. } & \multirow{4}{*}{ Town } & \multicolumn{6}{|c|}{ Mean indicator per cubic capacity $\left[\mathrm{W} / \mathrm{m}^{3}\right]$} \\
\hline & & \multicolumn{4}{|c|}{ Housing co-operatives } & \multirow{3}{*}{$\begin{array}{l}\text { Municipal } \\
\text { buildings }\end{array}$} & \multirow{3}{*}{$\begin{array}{c}\text { Public utility } \\
\text { facilities }\end{array}$} \\
\hline & & \multirow[t]{2}{*}[\mathbf{W}/\mathbf{m}^{3}]{} & \multirow{2}{*}{$\begin{array}{c}\text { Total number } \\
\text { of buildings }\end{array}$} & \multicolumn{2}{|c|}{$\begin{array}{c}\text { Number of cold } \\
\text { buildings } *\end{array}$} & & \\
\hline & & & & items & {$[\%]$} & & \\
\hline 1. & Siemiatycze & 24.4 & 82 & 42 & 51.20 & 25.0 & $19.0-27.0$ \\
\hline 2. & Pisz & 25.0 & 109 & 81 & 74.31 & 27.5 & $20.0-34.9$ \\
\hline 3. & Gizycko & 23.0 & 286 & 203 & 71.00 & 25.0 & $24.0-32.0$ \\
\hline 4. & Lomza & 22.5 & 354 & 243 & 68.64 & 25.8 & $18.0-53.0$ \\
\hline 5. & Suwalki & 20.0 & 416 & 238 & 57.20 & 23.2 & $17.1-34.0$ \\
\hline 6. & Hajnowka & 21.7 & 137 & 84 & 61.40 & 24.6 & $16.0-50.0$ \\
\hline 7. & Kolno & 23.35 & 57 & 45 & 78.90 & 27.18 & $22.0-35.2$ \\
\hline
\end{tabular}

*indicator per cubic capacity $>20 \mathrm{~W} / \mathrm{m}^{3}$, partitions in these buildings need additional thermal insulation 
Table 2 presents thermal characteristics of the analysed multi-family buildings in the form of mean indicators of heat load demand per cubic capacity for the purposes of central heating for residential housing by different towns, and also energy performance characteristics of municipal and public utility facilities (for comparison). The Table also shows the percentages of cold buildings in the group of all the analysed buildings.

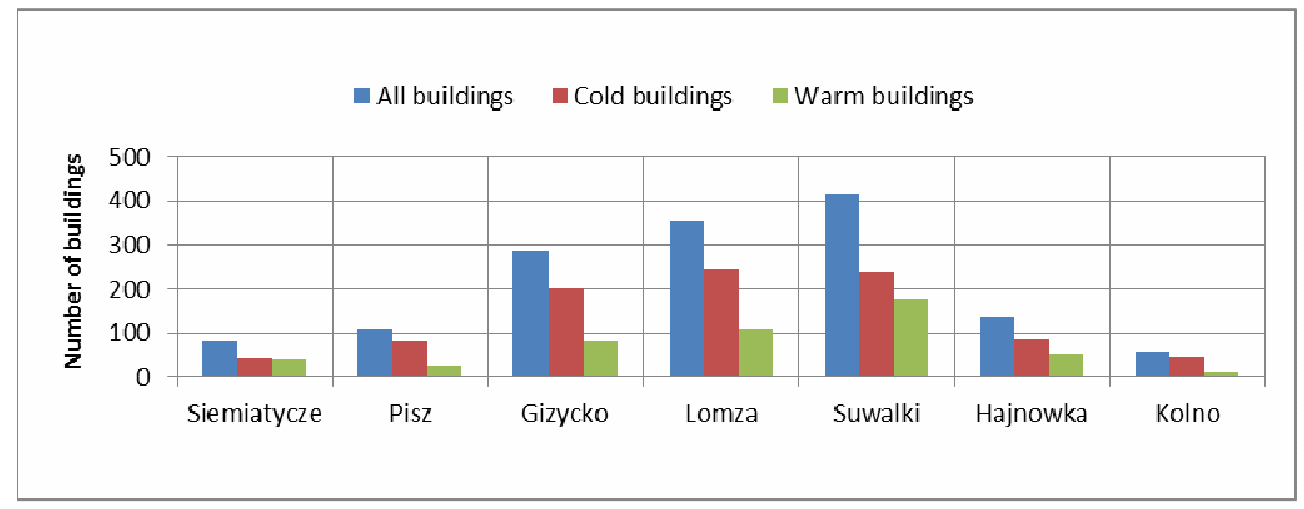

Fig. 1. Comparison of numbers of warm and cold multi-family buildings in the 7 analysed towns

On the basis of the data compared in Table 2 and Figure 1, it is possible to conclude that the majority of the buildings were characterised by much higher indicators than the recommended ones. In all the towns under concern, the percentage of cold buildings exceeded $50 \%$. This is indicative of great possible savings of energy for heating purposes. Only some of the multi-family buildings had been partially additionally thermally insulated (only the end walls) at the time the surveys were made (before the year 2000).

\section{Thermomodernization investments in multi-family buildings}

The saving potential in heat energy consumption in Poland is still very high - it amounts to approximately $100-170 \mathrm{kWh} /\left(\mathrm{m}^{2} \cdot \mathrm{a}\right)$, an equivalent of $15 \%$ of the present consumption, which is exemplified by the buildings under research $[2,11]$. In order to reach it, all buildings (both old and new ones) for which the $E$ indicator of heat load demand $\left[\mathrm{kWh} /\left(\mathrm{m}^{2} \cdot \mathrm{a}\right)\right]$ is much higher than the current requirements described in the Technical Specification, should undergo thermomodernization.

Considering the fact that more than $50 \%$ of the analysed buildings in all the towns listed above were characterised by excessive values of indicators of heat load demand per cubic capacity for heating purposes (Table 2, Fig. 1), comprehensive thermomodernization of these buildings is of significant importance in energy-saving heat management.

'Ordering' of the central heating and hot utility water systems is necessary directly after thermorenovation has been performed. An effective solution is to install thermostatic valves which allow for discounting heat gains (residential and solar). Making full use of the effects of the performed thermomodernization is possible only after the heat distribution centre (in the case of district remote heating) or the heat source (an own boiler house) has been modernised $[7,8]$. 
The percentages of heat loss through particular elements of a 'cold' multi-family and one-family building (the indicator per cubic capacity of $20-25 \mathrm{~W} / \mathrm{m}^{3}$ ) are presented in Figure 2.

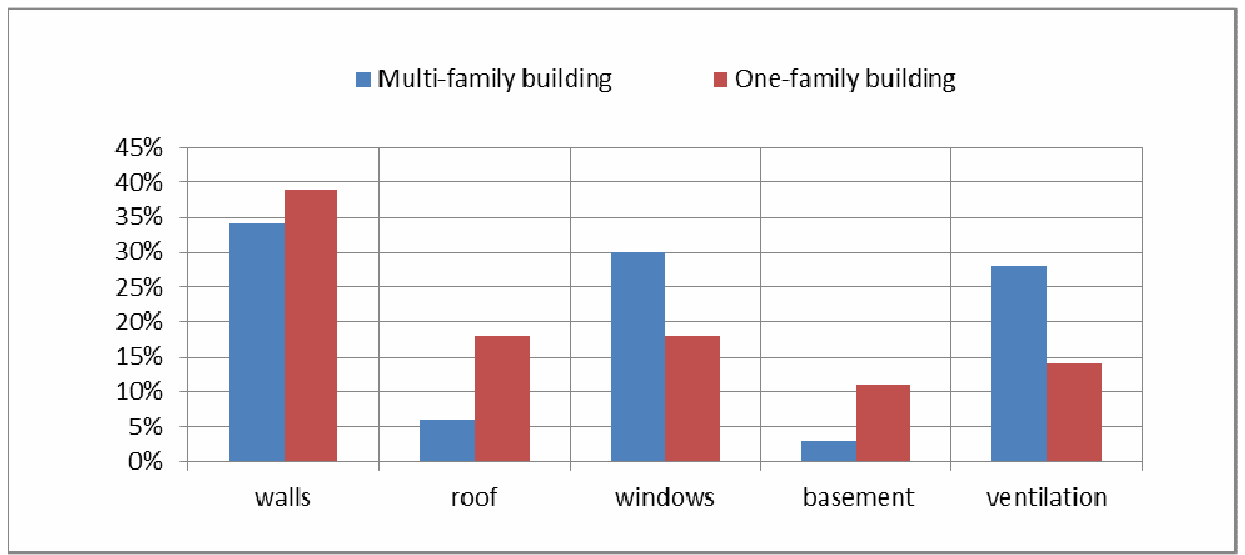

Fig. 2. Percentages of heat loss through particular elements and ventilation systems in a multi-family and one-family building

On the basis of the performed audit surveys of energy performance in selected multi-family buildings constructed with the use of industrialized technologies (prefabricated large-panel concrete, Zeranska brick) and in one-family buildings constructed using traditional technologies, reduction of heat loss through external walls and flat roofs as a result of the previous thermomodernization works were calculated. Figure 3 shows the data obtained in the analyses $[7,8]$.

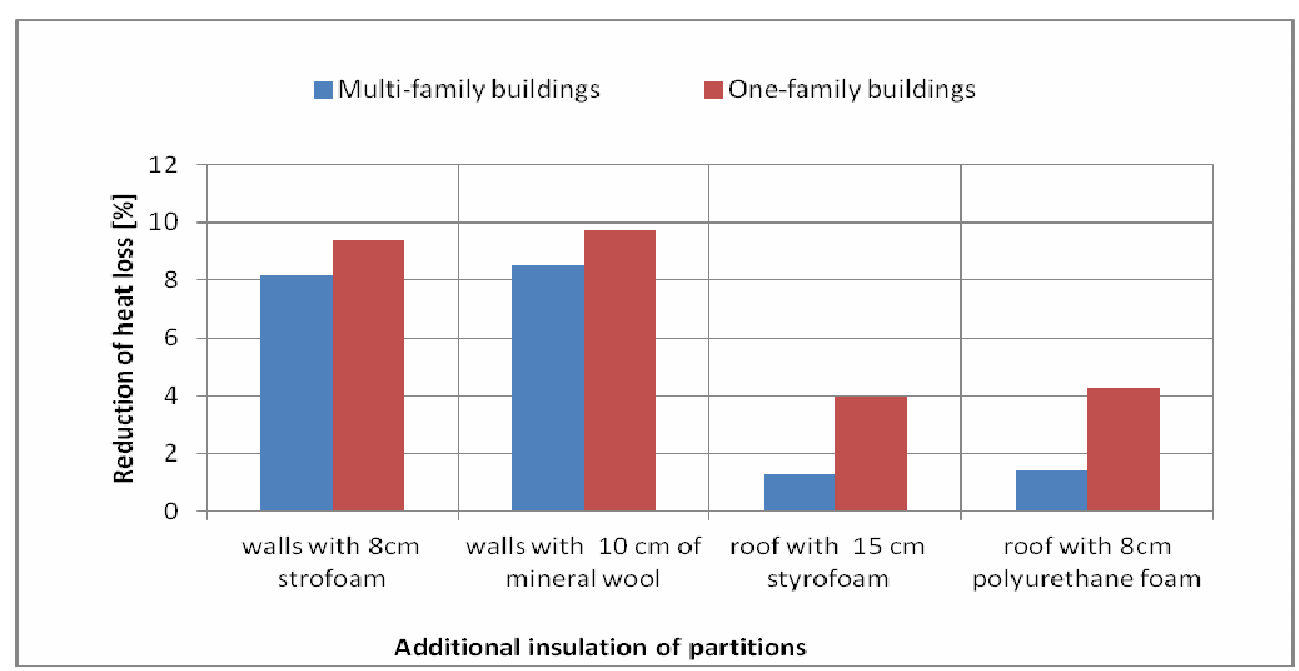

Fig. 3. Reduction (savings) in heat load demand as a result of additional insulation of external partitions (walls, ceilings) 


\section{Economic and 'ecological' analyses of thermomodernization works in multi-family buildings located in selected towns}

The analyses of the economic effectiveness of thermomodernization works (investments) were made for selected multi-family buildings constructed using industrialized technologies (prefabricated large-panel concrete, Zeranska brick). The 'Simple Pay Back Time' (SPBT) method was used for this purpose; the method does not take into consideration the influence of time on the value of money [11, 12]. Calculating the time (in years) after which the investment costs are paid back consisted in dividing the costs (the investment costs, the investment loan repayment, etc) resulting from implementing the project by the benefits stemming from savings in operating costs.

The aggregate heat load demand in multi-family buildings before and after a (possible) thermomodernization, the reduction in heat demand, and the economic effects (SPBT) are listed in Table 3.

Table 3

Aggregate heat load demand before and after thermomodernization, reduction in heat demand, and economic effects

\begin{tabular}{|c|c|c|c|c|c|c|c|c|}
\hline \multirow[b]{2}{*}{ No } & \multirow[b]{2}{*}{ Town } & \multicolumn{2}{|c|}{ Heat load demand [MW] } & \multicolumn{2}{|c|}{$\begin{array}{c}\text { Reduction in } \\
\text { heat load }\end{array}$} & \multicolumn{2}{|c|}{$\begin{array}{c}\text { Indicator per cubic } \\
\text { capacity }\left[\mathrm{W} / \mathrm{m}^{3}\right]\end{array}$} & \multirow{2}{*}{$\begin{array}{c}\begin{array}{c}\text { Economic } \\
\text { effects }\end{array} \\
\text { SPBT } \\
\text { [years]* }\end{array}$} \\
\hline & & $\begin{array}{c}\text { before } \\
\text { thermo- } \\
\text { modernization }\end{array}$ & $\begin{array}{c}\text { after } \\
\text { thermo- } \\
\text { modernization }\end{array}$ & $\Delta \mathbf{M W}$ & [\%] & $\begin{array}{c}\text { before } \\
\text { thermo- } \\
\text { moder- } \\
\text { nization }\end{array}$ & $\begin{array}{c}\text { after } \\
\text { thermo- } \\
\text { moder- } \\
\text { nization }\end{array}$ & \\
\hline 1. & Siemiatycze & 18.50 & 15.86 & 2.64 & 14.27 & 24.4 & $\sim 15.0$ & 13.0 \\
\hline 2. & Pisz & 27.70 & 22.30 & 5.40 & 19.49 & 25.0 & $\sim 15.0$ & 11.0 \\
\hline 3. & Gizycko & 39.20 & 33.76 & 5.44 & 13.87 & 23.0 & $\sim 15.0$ & 7.0 \\
\hline 4. & Lomza & 133.00 & 116.8 & 16.20 & 12.18 & 22.5 & $\sim 15.0$ & 8.9 \\
\hline 5. & Suwalki & 151.20 & 134.89 & 16.31 & 10.78 & 20.0 & $\sim 15.0$ & 10.0 \\
\hline 6. & Hajnowka & 35.00 & 29.40 & 5.60 & 16.00 & 21.7 & $\sim 15.0$ & 7.4 \\
\hline 7 & Kolno & 14.54 & 11.78 & 2.78 & 19.12 & 23.35 & $\sim 15.0$ & 11.3 \\
\hline
\end{tabular}

Drawing conclusions on profitability of thermomodernization investments on the basis of simplified methods is not sufficient. The 'Simple Pay Back Times' of some thermomodernization works are much similar, whereas their NPV (Net Present Value) indicators may turn out to be significantly different. Therefore, simple indicators can be applied only as auxiliary factors for making an initial assessment of profitability of a given project [11].

In the analysed towns, the SPBT values for 'full' thermomodernization ranged from 7 to 13 years. Such a long period of return of investment expenditures results from the fact that thermomodernization works are usually very expensive and such investment projects need to be very carefully prepared both in terms of technical issues and of profitability of the particular thermomodernization procedures $[7,8,12,13]$. 


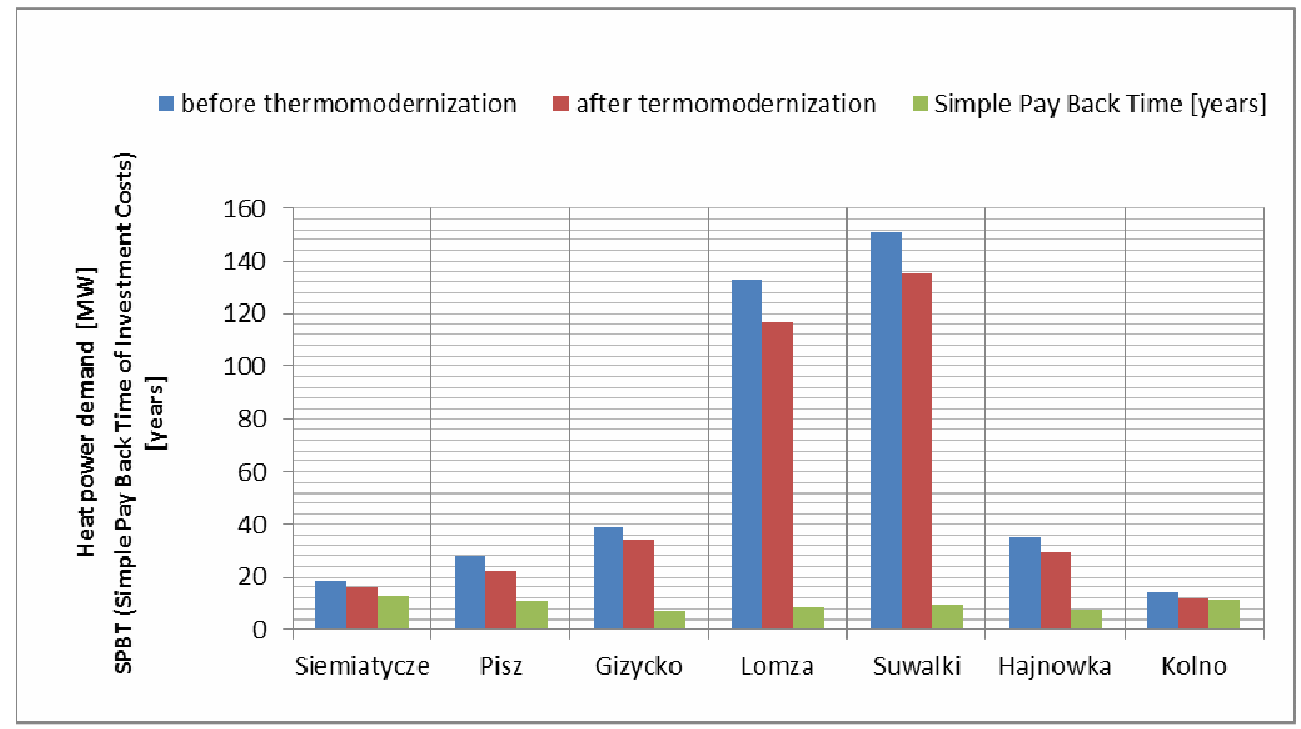

Fig. 4. Reduction of aggregate heat demand for heating as a result of thermomodernization works, and assessment of the investment effectiveness (SPBT)

\section{'Ecological' analysis - reduction of air pollution as a result of performed thermomodernization works}

When dealing with thermomodernization and urban district heating systems, one cannot neglect the important issue of environmental protection. Sources producing heat for buildings are the main contributors of air pollutants in urban areas and in their neighbourhood. Emission from small local boiler houses is particularly damaging because of their low emission sources. Practice shows that it is these small sources which are responsible for environment shaping in urban areas. The bigger the heat demand is (the more fuel is burned), the higher the air pollution is.

On the basis of the obtained data concerning the maximum fuel consumption by the particular central heating plants, the percentages of components in the used fuel, and other essential data, the values of particulate matter emission as well as sulphur dioxide $\left(\mathrm{SO}_{2}\right)$ unit-based emission were determined.

The ranges of spreading (dispersion) for the above pollutants were calculated according to a simplified Pasquill model (the pollution dispersion model is described with a differential equation of diffusion in the form of an analytic function based on the Gaussian distribution model) $[7,8,14]$.

This model accounts for the mean wind speed, the coefficients of horizontal and vertical atmospheric diffusion, the emission, and the height (from the ground level) at which concentrations of gas pollution are determined. The calculations were performed with the use of a numerical programme approved by the Institute of Environmental Protection.

Because of varied operating times of the emission sources of the boiler houses under research, and because of different conditions under which air pollution can be dispersed, the 
calculations were carried out in two sub-periods of time: in the heating (winter) period, and in the summer period [14].

The values of air pollutant emission from all the heat sources located within the limits of the analysed towns are presented in Figure 5.

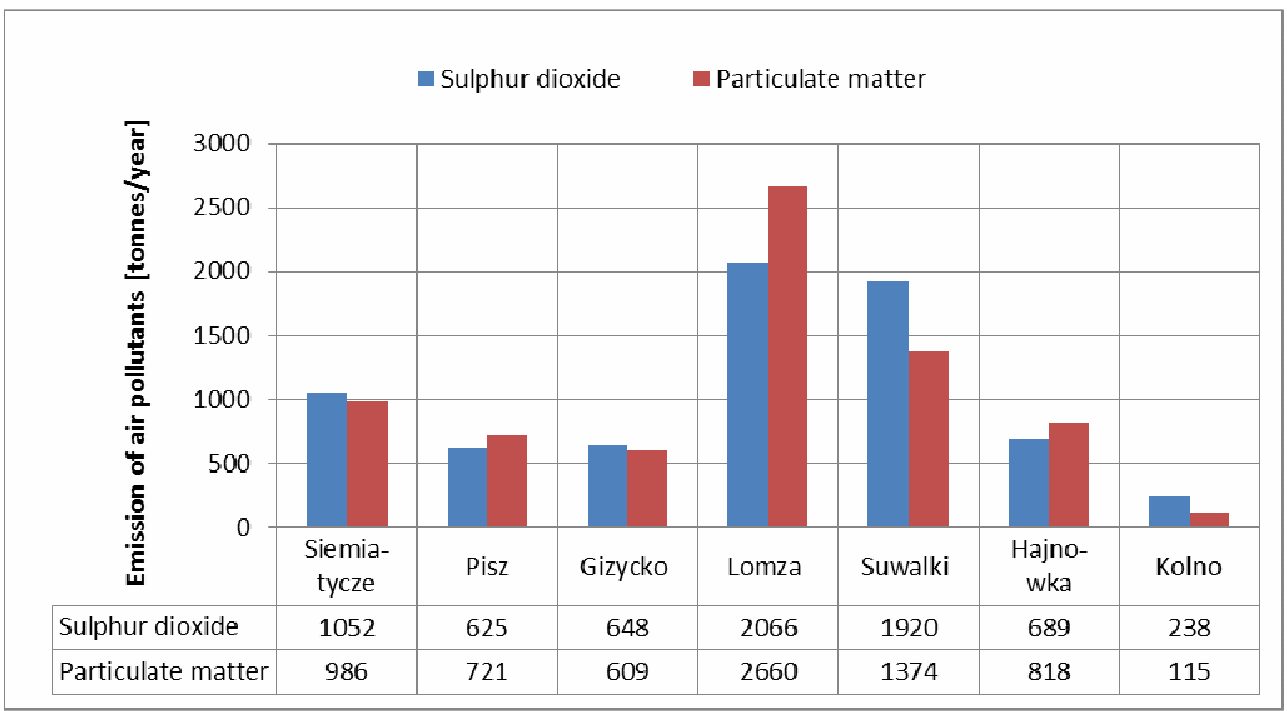

Fig. 5. Annual values of emission of selected air pollutants from existing boiler houses $\left(\mathrm{SO}_{2}\right.$ and particulate matter)

Parameters concerning the reduction of air pollution with $\mathrm{SO}_{2}$ and particulate matter, arrived at as a result of the performed thermomodernization works, are listed in Table 5.

Reduction of air pollution caused by lowering heat demand resulting from performing thermomodernization works

\begin{tabular}{|c|c|c|c|c|c|c|c|c|c|c|}
\hline \multirow{4}{*}{ No. } & \multirow{4}{*}{ Town } & \multirow{2}{*}{\multicolumn{2}{|c|}{$\begin{array}{c}\text { Pollutant } \\
\text { [tons/year] }\end{array}$}} & \multicolumn{7}{|c|}{$\begin{array}{c}\text { Air pollution reduction resulting from performing } \\
\text { thermomodernization works [tons/year] }\end{array}$} \\
\hline & & & & \multicolumn{3}{|c|}{ Mg/year for one MW } & \multicolumn{4}{|c|}{ Aggregate } \\
\hline & & \multirow{2}{*}{$\mathrm{SO}_{2}$} & \multirow{2}{*}{$\begin{array}{c}\text { particulate } \\
\text { matter }\end{array}$} & \multirow{2}{*}{$\mathrm{SO}_{2}$} & \multirow{2}{*}{$\begin{array}{c}\text { particulate } \\
\text { matter }\end{array}$} & \multirow{2}{*}{$\mathrm{CO}$} & \multicolumn{2}{|c|}{$\mathrm{SO}_{2}$} & \multicolumn{2}{|c|}{ Particulate matter } \\
\hline & & & & & & & [Mg/year] & {$[\%]$} & [Mg/year] & {$[\%]$} \\
\hline 1. & Siemiatycze & 1052 & 986 & 10.7 & 8.1 & 1.63 & 28.25 & 2.68 & 21.38 & 2.20 \\
\hline 2. & Pisz & 625 & 721 & 9.12 & 8.66 & 1.71 & 49.25 & 7.89 & 46.76 & 6.48 \\
\hline 3. & Gizycko & 648 & 609 & 8.23 & 7.26 & 1.6 & 44.77 & 6.90 & 39.49 & 6.50 \\
\hline 4. & Łomża & 2066 & 2660 & 7.15 & 9.24 & 0.5 & 115.83 & 6.60 & 149.69 & 5.63 \\
\hline 5. & Suwalki & 1920 & 1374 & 6.02 & 3.52 & 1.40 & 98.18 & 5.10 & 57.41 & 4.20 \\
\hline 6. & Hajnowka & 616 & 508 & 8.93 & 7.43 & 1.42 & 50.00 & 8.12 & 41.61 & 8.19 \\
\hline 7. & Kolno & 238 & 115 & 13.41 & 4.98 & 1.61 & 37.28 & 15.66 & 13.84 & 12.04 \\
\hline
\end{tabular}

*Siemiatycze had the highest percentage of warm buildings within the studied group of towns, hence the pollution reduction caused by thermomodernization was the lowest here 


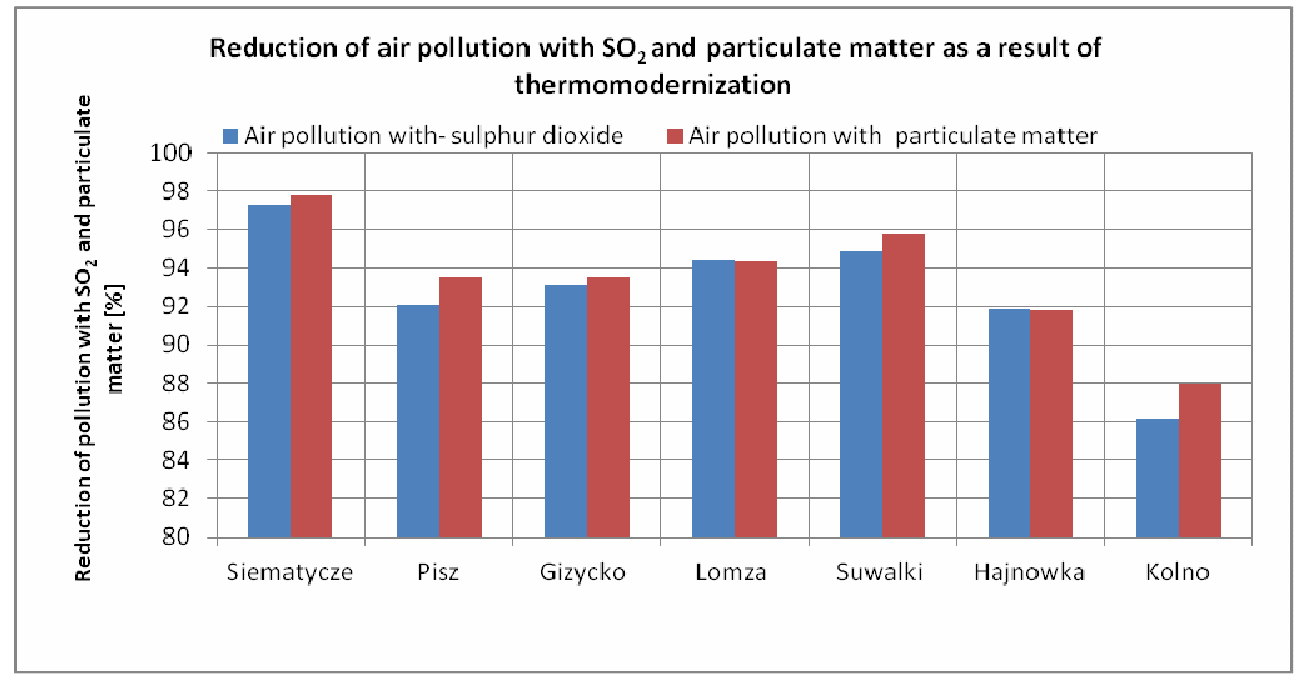

Fig. 6. Reduction of air pollution with sulphur dioxide and particulate matter, caused by performing thermomodernization of multi-family buildings

In the case of $\mathrm{SO}_{2}$, the reduction of air pollution resulting from the lowered heat demand (and, in consequence, from the smaller amount of combusted fuel), ranges from 2.68 to $15.66 \%$, whereas in the case of particulate matter it amounts from 3.52 to $9.24 \%$. Such high discrepancies between the obtained values are caused mainly by the percentage of the number of cold buildings (when compared to the total number of the buildings under research), at the assumption that all cold buildings undergo thermomodernization. The lowest reductions of air pollution (2.68 and 2.2\%) were observed in Siemiatycze in which the percentage of cold buildings was the lowest (51.2\%), while the highest reductions (13.84 and $12.04 \%$ ) were obtained for Kolno where the percentage of cold buildings was the highest $(78.9 \%)$.

\section{Summary and conclusions}

- Although more than 10 years had passed since the first surveys concerning 'The conception of energy-saving modernisation of heating systems' of selected towns in the north-eastern Poland, were made, some of the studied buildings (mainly public utility facilities) had not been additionally thermally insulated. It is estimated that the saving potential in heat energy consumption in Poland is still high and it amounts to approximately $100-150 \mathrm{kWh} / \mathrm{m}^{2}$, which means a reduction of the present consumption by $15 \%$ [3]. For that reason, it is necessary - for ecological reasons beside economic reasons - to ensure that all buildings in towns, not only housing ones but also public utility facilities, undergo comprehensive thermomodernization. It has to be pointed out that public utility buildings (schools, hospitals) are characterised by much worse indicators of heat demand per cubic capacity than housing buildings (Table 2) $[12,13]$.

- Before thermomodernization works start, audit surveys on energy performance of the buildings under concern should be made. On the basis of these surveys it is possible to 
determine the most economically effective method of accomplishing a particular investment. Only such a procedure guarantees obtaining an optimum reduction in heat demand [15-17].

- The effectiveness of thermorenovation works is influenced by the technical condition of a building, the thermoinsulating power of external partitions (the higher the value of the $U$ coefficient of heat transmission, the more beneficial they are), types of buildings, varied prices of additional thermal insulating of external partitions, and by current fuel prices. Considering the above, it is not straightforward to decide on the benefits of the particular works $[17,18]$.

- Only when combined with a 'reduced supply' of heat does additional thermal insulating of buildings produce a full saving effect which is expressed not only in economic but also in ecological benefits in the form of lowering emissions of harmful particulate matter and exhaust gases to the atmosphere as a result of reducing the amounts of combusted fuel.

- The presented analyses on the example of seven middle-sized towns show that performing well-thought out comprehensive thermomodernization of buildings makes it possible to save from a few (2.64-5.6) to several (16.2-16.31) MW of power at the heat sources, depending on the town size, which is significant for small towns. In the cases of such towns as Siemiatycze, Hajnowka, Kolno, or Gizycko, the increase in the prospective demand for heat power, caused by the development of the towns (new blocks of flats had been built) and by connecting old blocks of flats heated with furnaces to the district heating system (Table 1), was completely compensated by a diminished demand for heat power caused by carrying out thermomodernization works (data from 2010). Only in the cases of Pisz, Lomza, and Suwalki (where the increases in the heated cubic capacity $>10 \%$ ), it was necessary to perform additional investments connected with an increased demand for heat power.

- Beside financial benefits, reducing heat demand for heating purposes contributed to reducing air pollution with $\mathrm{SO}_{2}$ by 2.68 to $15.66 \%$, and also to reducing air pollution with particulate matter by 2.2 to $12.04 \%$ (depending on the town).

- In all of the towns under research, emission from the existing heating systems did not exceed the so-called ultimate condition of immission concerning the three calculated pollutants: sulphur dioxide, suspended particulate matter, and carbon monoxide within the whole area while the surveys were being conducted. However, if the conditions from before 1998 had been left unchanged (the number and technical conditions of emission sources as well as increased demands for heat power), then the concentration limits, mainly those of sulphur dioxide, would have been exceeded within significant parts of residential areas in the studied towns. Therefore, not only for economic reasons, it is necessary to ensure that all buildings in towns are properly thermally insulated, and heat energy sources which power them should be - wherever technically and financially feasible - ecological (biomass, solar energy, wind energy, hydroelectricity, etc) [19-21]. It also has to be taken into account that the Convention Protocol on long-range transboundary air pollution, called the 2nd Sulphur Protocol, imposed an obligation on Poland to significantly reduce emission of $\mathrm{SO}_{2}$ successively in the following manner: by $37 \%$ before 2000 , by $47 \%$ before 2005 , and by $66 \%$ before 2010 [5, 12]. 


\section{References}

[1] Boonekamp P. Trends and policies for space heating in the EU-27. Conference „Energy Efficiency in Buildings - Improving the database". Berlin: 2008.

[2] Bochenek D. Environment 2012. Statistical Information and Elaborations. Warsaw: 2012;211-225.

[3] Pawłowski A. The role of environmental engineering in introducing sustainable development. Ecol Chem Eng S. 2010;17(3):263-278.

[4] Domínguez S, Sendra JJ, Leon AL, Esquivias PM. Towards energy demand reduction in social housing buildings: envelope system optimization strategies. Energies. 2012;5(7):2263-2287. DOI: 10.3390/en5072263.

[5] Kanie N, Nishimoto H, Hijioka Y, Kameyama Y. Allocation and architecture in climate governance beyond Kyoto: lessons from interdisciplinary research on target setting. International Environmental Agreements: Politics, Law and Economics. 2010;10(4):299-315. DOI: 10.1007/s10784-010-9143-5.

[6] Li J. Towards a low-carbon future in China's building sector A review of energy and climate models forecast. Energy Policy. 2008;36(5):1736-1747.

[7] Ickiewicz I, Stempniak A, Nytko K. Concept of energy-saving modernization of district heating system in Suwalki, Gizycko Lomza, Hajnowka, with account for prospective development of the town. Białystok: NECA; 2010.

[8] Ickiewicz I, Stempniak A, Nytko K. Design assumptions for a heat supply plan for the town of Pisz, Siemiatycze, Kolno. Bialystok: NECA; 2010.

[9] Boron W, Chomiak A, Kawa A, Zawora A. Using renewable energy sources and their influence on the energy performance of buildings. Dissertations and Monographs. Institute of Innovative Technologies EMAG. Katowice 2012.

[10] Karganov S. Evaluation of economic effectiveness of investment activity. Materials of International Scientific and Technical Conference Expol-Ship (IV). Stettin 2006.

[11] Thermal modernization of public utility buildings in Kolno town - conference materials - financing thermal modernization works in residential and public buildings by the ESCO Energy Saving Company Ltd. Krakow 2007.

[12] Rybkowska I, Siuta-Olcha A. The evaluation of energy-consumption of the school building before and after the thermo-modernization. Polish Academy of Sciences. The Committee on Environmental Engineering, Monographs: Polish environmental engineering after five years in the European Union 2009;3(60):207-216.

[13] Third Assessment Report, Intergovernmental Panel on Climate Change (IPCC) 2000.

[14] Kryza M, Mill W, Dore AJ, Werner M, Blas M. Calculation of sulphur and nitrogen deposition with the frame model and assessment of the exceedance of critical loads in Poland. Ecol Chem Eng S. 2013;20(2):279-290. DOI: 10.2478/eces-2013-0020.

[15] Liu G, Liu H. Using insulation in china's buildings: potential for significant energy savings and carbon emission reductions. Low Carbon Economy. 2011;2:220-223. DOI: 10.4236/lce.2011.24027.

[16] Norwisz J. Building thermomodernization for improving the quality of the environment. Gliwice: The Library of Energy Conservation Foundation; 2004.

[17] Pawłowski A. Sustainable development and environemntal engineering. Polish Academy of Sciences. The Committee on Environmental Engineering, Monographs: Polish environmental engineering after five years in the European Union. 2009;3(60):17-33.

[18] Ickiewicz I. Ecological and economic aspects of modernizing district heating systems in north-eastern Poland. Ecol Chem Eng S. 2011;18(4):429-442.

[19] Liu KS, Hsueh SL, Wu WC, Chen YL. A DFuzzy-DAHP Decision-Making Model for Evaluating Energy-Saving Design Strategies for Residential Buildings. Energies. 2012;5(11):4462-4480. DOI: 10.3390/en5114462.

[20] Lukić P, Tamburić J, Stojić D. Energy efficiency of buildings with phase-change materials. Facta Universitatis Series: Architecture and Civil Engineering. 2012;10(3):353-360. DOI: 10.2298/FUACE1203343L.

[21] Turnić D, Dimitrijević Ž, Stanković D. Housing facilities management in the Republic of Serbia from the aspect of energy efficiency improvement. Facta Universitatis Series: Architecture and Civil Engineering 2012;10(3):353-360. DOI: 10.2298/FUACE1203353T. 


\title{
TERMOMODERNIZACJA BUDYNKÓW A REDUKCJA ZANIECZYSZCZENIA POWIETRZA
}

\author{
Wydział Budownictwa i Ochrony Środowiska, Politechnika Białostocka
}

\begin{abstract}
Abstrakt: Przedstawiono analizę techniczno-ekonomiczną prac termomodernizacyjnych budynków mieszkalnych wielorodzinnych i użyteczności publicznej wykonanych w technologii uprzemysłowionej (OWT, Cegła Żerańska) oraz technologii tradycyjnej, zrealizowanych przed 1990 rokiem. Oceniono 1441 budynków zlokalizowanych w 7 miastach. Miernikiem energochłonności budynków był wskaźnik kubaturowego zapotrzebowania na moc cieplną, który określono na podstawie wizji lokalnych i dokumentacji technicznej. Otrzymane wyniki wykorzystano do analizy opłacalności zaproponowanych prac termomodernizacyjnych. Jako kryterium opłacalności inwestycji przyjęto „Prosty Okres Zwrotu” (SPBT), redukcję zanieczyszczenia powietrza pyłami i tlenkiem siarki, zaoszczędzenie mocy cieplnej (wynoszącej kilka, a nawet kilkanaście MW, które w skali małego miasta często są wystarczające na pokrycie perspektywicznego przyrostu zapotrzebowania na moc cieplną).
\end{abstract}

Słowa kluczowe: termomodernizacja, obniżenie mocy zamówionej, analiza ekonomiczna, redukcja zanieczyszczenia powietrza 